\title{
Crivella e a Igreja Universal: inserção no espaço público, estratégias e política eleitoral
}

Gabriel Rezende

\section{RESUMO}

A proposta do presente artigo é compreender como a identidade religiosa perpassa os campos normativos e racionais da esfera pública, enalteceremos assim, a Igreja Universal do Reino de Deus (IURD) e os seus contornos políticos partidários. Em que se objetiva tratar do modus operandi político da IURD, prefigurando os pleitos disputados pelo político e bispo licenciado da Igreja Universal, Marcelo Crivella, em suas sucessivas campanhas para o executivo fluminense e carioca: 2004, 2006, 2008, 2014; antes de sua vitória em 2016. Demonstrando a presença/circulação indiscutível do religioso em busca de eficácia política, que gera um adensamento em discursos político-religiosos como fonte de capital social.

Palavras-chave: Comportamento político iurdiano; Eleição executiva carioca; Marcelo Crivella.

\begin{abstract}
The purpose of this article is to understand how religious identity permeates the normative and rational fields, thus enhancing the role of neo-pentecostalism, in a primordial way the Universal Church of the Kingdom of God, as well as its practices (2006), Smirdele (2013), Machado (2006) and Mariano (2006; 2009). In other words, the propose is to deal with the political modus operandi of the IURD, prefiguring Marcelo Crivella, politician and licensed bishop of the Universal Church,
\end{abstract}

${ }^{1}$ Mestre em Sociologia Política pelo Instituto Universitário de Pesquisas do Rio de Janeiro (IUPERJ) e Bacharel em Relações Internacionais pela Universidade Cândido Mendes (UCAM/RJ). E-mail: gabrielsrezende@hotmail.com. 
in the political party context (in his successive campaigns for the Rio de Janeiro State and the Rio de Janeiro city hall (2004, 2006, 2008, 2014, before his victory in 2016) demonstrating the indisputable presence of the religious in search of political efficacy, which generates a deepening of political-religious discourses as a source of social capital.

Keywords: Pentecostal political behavior; Rio de Janeiro city election; Universal Church of the Kingdom of God.

Com discreta participação no cenário político até os anos de 1970, os evangélicos ganharam visibilidade nas eleições de 1986 para a formação da assembleia constituinte de 1988, iniciando uma nova presença protestante em termos quantitativos ${ }^{2}$ e qualitativos, em relação a novas igrejas representadas, novos tipos de políticos e estratégias de ação. $\mathrm{O}$ Brasil passou a ser, nessa eleição, o primeiro exemplo de presença eleitoral e parlamentar significativa por parte de minoria protestante num país de tradição católica. Dado que, a maioria de seus representantes se posicionaram de maneira alinhada nas discussões parlamentares, atuando como uma bancada religiosa, particularmente, a evangélica. ${ }^{3}$ Sendo o comportamento desses atores marcado naquele contexto, como destaca Machado (2006), pelo conservadorismo, corporativismo e a debilidade das teses do apoliticismo de certos setores evangélicos.

É notório não somente nos noticiários, mas nos estudos sociais (que já realizam pesquisas sobre o papel religioso na política há mais de 30 anos) que no cenário contemporâneo as temáticas e argumentos religiosos vêm ganhando destaque nas eleições brasileiras. Tal ênfase resulta da crescente participação pentecostal na política nacional, como

\footnotetext{
${ }^{2}$ Segundo Freston (1993), de 2 para 18 deputados federais naquele período.

${ }^{3}$ Entrando em convergência com os setores católicos no Congresso Nacional, principalmente em questões relativas ao aborto entre outras temáticas relativas.
} 
muito analisado em Oro (2003; 2006), Smirdele (2013), Machado (2006) e Mariano (2006; 2009). Em conjunto com a expansão demográfica exponencial desse grupo acelerada desde a década de 1980 conforme destaca Mariano (2000). Segundo o Censo de 2010 do IBGE (Instituto Brasileiro de Geografia e Estatística) havia cerca de 42,3 milhões de evangélicos no país, o que representava $22,2 \%$ da população brasileira. $\mathrm{O}$ Pew Research Center também publicou um estudo recente realizado entre 2013 e 2014 em que os protestantes já representavam 26\% da população brasileira. ${ }^{4}$

A literatura nos aponta, como assevera Trevisan (2013), que os pentecostais ingressam na política em defesa dos seus interesses religiosos e da manutenção da moral cristã e dos bons costumes. De fato, algumas denominações neopentecostais têm mostrado maior êxito em seus desafios eleitorais e de inserção na mídia, se comparados às demais denominações, em especial às do protestantismo histórico. Em concomitância com a análise de Marcelo Tadvald (2015) que aponta que partir do modelo instaurado pela Igreja Universal do Reino de Deus (IURD) desde as eleições constituintes de 1986, as igrejas que obtêm maior sucesso nesta arena são aquelas que possuem projetos mais bem definidos de inserção na política e que utilizam seus templos e demais espaços religiosos, para fazer campanha para seus candidatos, dispondo de meios materiais e midiáticos que contribuem na difusão das campanhas entre os seus fiéis e até para além deles.

Apresentaremos assim, ao longo deste artigo, a análise sobre a constituição da IURD, sua estrutura e estratégias políticas, bem como as candidaturas de seu principal expoente político, Marcelo Crivella. Nos atentaremos, de modo especial, aos pelitos eleitorais disputados pelo bispo licenciado da IURD e ex-senador Crivella nas eleições

${ }^{4}$ Dados disponíveis em: <https://www.pewforum.org/2014/11/13/religion-inlatin-america/>. Acessado em: 29/07/2018. 
predecessoras a de 2016. De modo que a eleição municipal carioca de 2016 - explorado em trabalho anterior (REZENDE, 2017) - colocou pela primeira vez em uma das principais capitais do país e ex-capital do Brasil um bispo evangélico. Portanto, é de fulcral importância analisarmos as estratégias e os discursos presentes nas eleições anteriores que, de certa forma, corroboram para a compreensão das dinâmicas eleitorais que levaram Crivella a ocupar o mais alto cargo executivo municipal em 2016 e como uma forma de analisar de um nível macro a estrutura e a constituição da IURD na esfera política brasileira nas últimas décadas.

\section{IURD: formação e desenvolvimento sócio-político}

A IURD surgiu na sala de uma ex-funerária do bairro da Abolição, subúrbio da zona norte da cidade do Rio de Janeiro, em 1977, sob a articulação de Edir Bezerra Macedo e Romildo Soares. ${ }^{5}$ Teria como destino mais provável, como tantos grupos pentecostais, ficar confinada na periferia ou na disputa de espaço religioso nos morros e favelas do Rio, porém a IURD conseguiu em poucos anos o que levaria décadas para outros grupos pentecostais, a diversificação de sua base social, como aponta Freston (1993). Sua expansão geográfica é assimétrica, com forte concentração no Rio de Janeiro (capital e baixada) e em São Paulo e Salvador, é sobretudo uma religião das grandes cidades. Bem como se faz presente no exterior, em quase toda América do Sul, Portugal, Estados Unidos e Angola.

Sua expansão se deve, em grande medida, à sua eficiência no uso dos meios de comunicação de massa, sobretudo em rádio e televisão. Em fins dos anos 1990, Edir Macedo (fundador e bispo da IURD), pastores e demais bispos de sua confiança eram proprietários de um verdadeiro

\footnotetext{
${ }^{5}$ Que devido a dissidências internas com Macedo, se separa e funda a Igreja Internacional da Graça de Deus (1980).
} 
império de comunicação que quanto mais crescia incomodava a concorrência religiosa e empresarial. De modo expressivo, a compra da TV RECORD, rede nacional em expansão e cuja a programação e administração foram reestruturadas com os recursos da igreja, além da Folha Universal, jornal da IURD, com mais de um milhão e meio de exemplares, agindo como principal veículo de proselitismo (MARIANO, 1999).

Em 1989, Macedo transfere a sede da IURD do Rio para São Paulo e adquiri e reestrutura a TV RECORD, ao mesmo tempo que nesse mesmo ano eleitoral percebia a necessidade de respaldo político para construir uma base sólida para seus projetos, lembrando que as concessões para os meios de comunicação necessitam - até hoje - de decisões políticas. Não à toa, Macedo acena positivamente para a campanha presidencial de Fernando Collor de Mello, bem como consegue eleger três deputados federias, dois deputados estaduais no Rio, um em São Paulo e um na Bahia com seu apoio (Freston, 1933). ${ }^{6}$

Demonstrando a capacidade da disciplina eleitoral da IURD dentre as demais igrejas pentecostais. De acordo com Freston, nesse mesmo período: o "voto da Universal no Rio foi dividido por computador para garantir uma distribuição capaz de eleger dois deputados federais. Um deles residia em São Paulo e quase não precisou ir ao Rio, tal eficiência dos pastores como cabos eleitorais" (1993, p. 97). O que reafirma uma postura altamente pragmática com a política, em que todos os eleitos alegam a necessidade de defender os interesses da igreja - e da RECORD - dentro do Congresso Nacional ou nas Assembleias Legislativas. Portanto, sua forte inserção na mídia e na política partidária, sua competência administrativa, agilidade na expansão no Brasil e no exterior, e a capacidade de mobilizar inúmeros fiéis em

${ }^{6}$ A força política que Macedo buscou alicerçar não foi nenhum pouco desprezível (votos, dinheiro, TV e rádios), como foi demonstrado durante sua prisão em 1992. Para mais informações ver: Freston, 1993. 
diversos Estados não encontram paralelo em nenhuma outra organização protestante brasileira (MARIANO, 1999).

A politização dos coletivos evangélicos é um fenômeno que se verifica em outros países do continente latino-americano, em 1990, na esteira desses acontecimentos várias pesquisas acadêmicas foram realizadas sobre o comportamento político desse segmento religioso como na Guatemala, Nicarágua, El Salvador, Peru e Costa Rica (MACHADO, 2006). ${ }^{7}$ Bem como podemos aludir o apoio político do movimento evangélico Maioria $\mathrm{Moral}^{8}$ a Ronald Regan e, posteriormente, a George W. Bush - pós 11/o9/2001 -, em que as propostas conservadoras desses dois presidentes norte-americanos, como argumenta Machado, “constituíram experiências paradigmáticas que alimentaram especulações nos setores que formam a opinião pública brasileira e propiciaram o engajamento de novos atores sociais na discussão sobre a publicização das religiões: os militantes dos movimentos gays" (2006, p. 17-18). Como uma agência reativa ambivalente, provinda do antagonismo discursivo presente nas contingências daquele período.

É interessante observar, como explicita Machado, o apoio eleitoral de segmentos evangélicos - históricos e pentecostais - aos candidatos Hugo Chavez, na Venezuela em 1998, e a Luiz Inácio Lula da Silva, no Brasil em 2002, o que segundo a autora, revelaria que a heterogeneidade identificada nas doutrinas e práticas religiosas poderia estar presente na arena política em determinados contextos históricos. Desse modo, ao invés de tratar os grupos religiosos como coletivos

\footnotetext{
${ }^{7}$ Para mais informações sobre as pesquisas ver Machado (2006).

${ }^{8}$ (Moral Majority) é um grupo de pressão norte-americano fundado em 1979, ligado à chamada nova direita. Dirigido pelo reverendo Jerry Falwell e ligado a movimentos de fundamentalismo cristão. Entre outras posições, o grupo defendia a prática de orações e o ensino do criacionismo nas escolas públicas e se opunha à emenda da igualdade de direitos, ao homossexualismo e ao aborto. Foi extinto enquanto movimento em 1989, todavia, foi rearticulado após o 11/09/2001.
} 
monolíticos politicamente é muito mais plausível analisar as múltiplas possiblidades de articulação do ethos religioso com o comportamento eleitoral e político; a tentativa de legitimação na esfera pública; e a relação institucional com os fiéis.

Por conseguinte, o avanço do processo de pentecostalização do campo evangélico, tende, a demonstrar uma espécie de reafirmação da esfera religiosa para compreensão do mundo político, ao contrário, da tendência moderna da laicização do Estado e da pertença religiosa correspondente a esfera privada do indivíduo. A abordagem literária acerca do engajamento político pentecostal, em Smirdele (2013), Mariano (2001), Oro (2003) entre outros, identificaram pré-condições que tornam os fiéis pentecostais predispostos ao engajamento político-eleitoral, quando estimulados por lideranças eclesiásticas e carismáticas. Ou seja, a organização religiosa estimula a mobilização dos fiéis para fins eleitorais. Todavia, o neoconservadorismo evangélico não é um dado isolado, é parte de um contexto de fortalecimento de posturas conservadoras na esfera pública brasileira em geral.

Em que a atuação de grupos e organizações religiosas no contexto brasileiro é percebido pela interação entre governos e organizações religiosas, na implementação de programas sociais ou devido ao caráter representativo dos grupos religiosos na política nacional, bem como da necessidade dos crescentes votos evangélicos em todos os níveis do Estado (Federal, Estadual e Municipal). Fato evidenciado nas eleições de 2014 quando candidatos como: Dilma Rousseff, Michel Temer e Geraldo Alckmin visitaram o Templo de Salomão, pertencente à Igreja Universal de Edir Macedo em São Paulo, e em 2016 a presença constante de João Doria com líderes evangélicos. ${ }^{9}$

9 Disponível em: <http://www1.folha.uol.com.br/poder/2017/o7/1899489doria-recebe-pastores-na-prefeitura-e-ouve-que-deus-tem-outros-voos-paravoce.shtml>. Acessado em: 29/11/2017. 
Além da constante participação e apoio de líderes evangélicos na candidatura de Jair Bolsonaro em 2018 como Silas Malafaia e Magno Malta, bem como a tensão entre Fernando Haddad e Edir Macedo ao longo do pleito. ${ }^{10}$

Ademais, o intenso relacionamento entre organizações religiosas e outras organizações da sociedade civil, a exemplo: sindicatos e ONG's; propiciam a complexa presença de grupos religiosos em constante articulação com sociedade civil através de assistencialismo e ações comunitárias. Reforçando assim, as confluências política e sociais com a religião dentro do espaço público, logo, a potencialidade da instituição religiosa. Com tudo isto, a presença da religião cristã da vertente evangélica (de modo especial, dissociando em certos aspectos do monopólio outrora católico) no espaço público e na política não pode ser interpretada como via exclusiva de ameaça (retrocesso) por parte do setor mais progressista, mas como fator revelador do próprio avanço da democracia.

As transformações nos quadros socioculturais e políticos, em especial, na última década têm intensificado estudos acadêmicos e chamado atenção do público interessado nas questões que envolvem religião no Brasil. Podemos identificar nesta transformação a articulação de três fenômenos interligados entre si como aponta Cunha (2016): (I) o fortalecimento do ramo pentecostal, com o surgimento de inúmeras igrejas autônomas que transformou o cenário do cristianismo, ao provocar um crescimento significativo em termos numéricos e geográficos da população evangélica e uma forte queda do número de católicos; (II) a ampliação da presença das igrejas evangélicas, majoritariamente pentecostais, nas mídias ( digitais e tradicionais); (III) maior ocupação de espaço pelos evangélicos na política partidária, com a

1o Disponível em: <https://www1.folha.uol.com.br/poder/2018/10/edirmacedo-processa-haddad-apos-ser-associado-a-fundamentalismocharlatao.shtml?loggedpaywall>. 
consequente consolidação da bancada evangélica, e seu maior espaço de articulação, a Frente Parlamentar Evangélica (FPE). Bem como a forte presença do tripé: política, mídia e assistência social, analisado por Machado (2006); que em síntese, essas três características, sustentam o projeto da IURD de ampliação de sua capacidade de influência na esfera pública brasileira.

\section{Situando a candidatura de Crivella}

Desde as eleições de 1988 os partidos políticos têm demonstrado crescente interesse nos pentecostais através do incentivo à filiação partidária de lideranças religiosas, favorecendo não somente a entrada desses religiosos na política, mas também o norteamento dos partidos, como aponta Machado (2012a).

Dentre essa profusão de candidaturas destacamos a eleição de 2014, na qual dos mais de 26 mil políticos que concorreram a algum cargo público, 328 tiveram seus nomes nas urnas acompanhados das palavras missionário, pastor ou bispo, demonstrando o reflexo da ampliação evangélica no país. Como apresentado anteriormente, em 2010, a proporção de evangélicos atingiu 22,2\% da população. Já os dados da Pew Research Center entre 2013 e 2014 apontam que os protestantes já representavam $26 \%$ da população brasileira.

Todavia, na prática eleitoral tal montante de votos não é capaz de decidir uma eleição executiva, uma vez que não alcançam sozinhos (sem nenhum tipo de coalizão/coligação) a metade dos votos necessários

para eleger governadores ou presidente. Além disso, as posturas institucionais de algumas igrejas não são uniformes, que em muitos casos inviabilizaria este processo. Contudo, nas eleições proporcionais (nas instâncias legislativas), a capacidade de elegerem representantes aumenta. Essas informações confirmam as análises de pesquisadores 
como Machado (2006), Oro (2003) e Smirdele (2013) acerca da participação evangélica no sistema político brasileiro, em que se concentram nas disputas do poder legislativo em detrimento ao poder executivo, no qual poucos atores religiosos almejaram o pleito, seja por motivações ou estratégias institucionais das igrejas ou até mesmo por razões pessoais.

Mesmo havendo algumas incursões políticas de candidatos nominalmente evangélicos no executivo - como o caso da eleição de Anthony Garotinho ${ }^{11}$ para o governo do Estado do Rio de Janeiro (19992001), tendo disputado a presidência da República em 2002 e sua capacidade de eleger sua esposa, também evangélica, Rosinha Garotinho como governadora do Estado (2003-2007). As vitórias de candidatos evangélicos em pleitos majoritários não seguiram um padrão de uniformidade no campo religioso, pois poucos candidatos lograram resultados satisfatórios nas eleições concorridas. Nas eleições presidenciais de 2014, o pastor Everaldo Pereira no primeiro turno recebeu 780.513 votos $(0,75 \%)$ e foi o quinto candidato mais votado. Superado por Dilma Rousseff (PT), Aécio (PSDB), Marina Silva (PSB) e Luciana Genro (PSOL).

As candidaturas de Marcelo Crivella não foram diferentes. O bispo licenciado da IURD disputou ao longo de sua carreira política iniciada em 2002, sete eleições, dentre elas, cinco para o executivo

${ }^{11}$ É importante salientar as diferenças entre o ex-governador do Rio de Janeiro, Anthony Garotinho, e o atual prefeito da cidade do Rio de Janeiro, Marcelo Crivella. Garotinho já era político (vereador e prefeito) na cidade de Campos dos Goytacazes (RJ), deputado estadual, assumiu a pasta da Secretária Estadual da Agricultura no governo estadual de Brizola, até 1994, quando foi candidato ao governo do estado do Rio, vindo a ser derrotado, sobretudo pela imagem negativa de Brizola, sendo somente eleito governador em 1998. Ou seja, Garotinho já era conhecido como político antes mesmo de ser evangélico, convertendo-se somente após um acidente de carro e em julho de 1995, sendo batizado na Igreja Presbiteriana. Enquanto Marcelo Crivella, entrou na política em 2002, disputando uma cadeira no senado pelo Estado do Rio de Janeiro, já como bispo licenciado da Igreja Universal do Reino de Deus, transparecendo, apesar das tentativas de dissociação, forte identidade evangélica com sua denominação. 
carioca ou fluminense (2004, 2006, 2008, 2014, 2016) e duas legislativas, para o Senado em 2002 e 2010. Obteve vitória nas duas disputas para o Senado e não obteve nenhuma vitória em pleitos executivos, sendo a única exceção até o momento, as eleições de 2016, quando conquistou a prefeitura da cidade do Rio de Janeiro.

\section{Crivella e a IURD: estratégias políticas e dinâmica eleitoral}

Marcelo Bezerra Crivella é natural do Rio de Janeiro e sobrinho de Edir Macedo. Foi peça chave para a implementação da Igreja Universal na África do Sul. Formado em engenharia, bispo, cantor e compositor de música gospel, tornou-se um dos líderes evangélicos mais conhecidos no Brasil nos anos de 1990, através do Projeto Nordeste, implementado no sertão da Bahia. Apresentava a possibilidade de desenvolver o sertão através de processos alternativos à irrigação, ou seja, realizando atividades de assistência social na Fazenda Canaã.

Como debatido, dentre as denominações do campo pentecostal, destacamos neste trabalho a Igreja Universal do Reino de Deus (IURD) por ser a denominação de Crivella e devido ao seu uso intensivo e extensivo da mídia e da capilaridade de um discurso que traz para o campo político elementos significativos do simbolismo religioso. Esse sucesso reproduziria um efeito mimético em outras igrejas que, assim como a IURD, almejam expressar seu capital político e poder institucional, causando interesse e alianças com os partidos políticos (ORO, 2003). Freston (1993) argumenta que a política corporativista de algumas igrejas pentecostais busca: fortalecer lideranças internas, proteger a socialização sectária, acessar recursos para a expansão religiosa e disputar espaços na religião civil.

Para Ari Oro (2003), o sucesso eleitoral da IURD decorre de um próprio modo de fazer política que ela adotou a partir de 1997 em âmbito 
nacional (desde 1977, ela já adotara a estratégia política a seguir, porém, somente no Estado do Rio de Janeiro). Trata-se do modelo corporativo da "candidatura oficial", cujo número dos que pleiteiam cargos eletivos depende do potencial eleitoral de que dispõe. Para isso, a IURD recorria a um levantamento regionalizado de seus membros/fiéis que são eleitores e transmitiam os dados para os bispos que, deste modo, deliberavam quantos candidatos deveriam lançar em cada município ou Estado, obedecendo a lógica do tipo de eleição, baseados no quociente eleitoral dos partidos e no número de eleitores das igrejas. Após a escolha desses candidatos/representantes da igreja, são usados cultos, concentrações em massa e a própria mídia que possuem (televisão, rádios e jornais como a Folha Universal) para fazer publicidade em favor desses.

Outro fator estratégico que estimula a participação de membros/fiéis iurdianos na política, segundo Oro (2003), é o “carisma institucional" que legitima as determinações políticas das lideranças da IURD, escolhendo os candidatos a cargos eletivos com o apoio da igreja. Esse fato revela a força de uma hierarquia institucional, ou seja, uma centralização em que a denominação define os indivíduos que poderão concorrer nas eleições, logo, os candidatos "representantes da igreja”.

A IURD, por meio de uma estratégia baseada no quociente eleitoral dos partidos, distribuía seus candidatos em diferentes partidos, vislumbrando alcançar o maior grau de barganha política, todavia, em alguns casos, seus interesses se sobrepunham aos da legenda partidária dos partidos filiados (ORO, 2006, p. 121). Até então, o partido que a igreja mais tinha se envolvido foi o Partido Liberal (PL), profundamente abalado em 2005 com o escândalo do mensalão ${ }^{12}$ que provocou

${ }^{12} \mathrm{O}$ Mensalão foi o esquema de pagamento de propina a parlamentares para que votassem a favor de projetos do governo, sendo o principal escândalo no primeiro mandato de Luiz Inácio Lula da Silva (PT). Foi revelado em 2005, quando o jornal Folha de S. Paulo publicou uma entrevista com o deputado federal Roberto Jefferson (PTB- 
reviravolta no ordenamento político brasileiro. Esse evento fez com que a cúpula da IURD procurasse uma nova alternativa, quando em Agosto de 2005 criou o Partido Municipalista Renovador (PMR), com o registro definitivo do Tribunal Superior Eleitoral (TSE). Alguns meses depois, a nova legenda partidária recebeu como filiado o então vice-presidente da República José Alencar e alterou sua denominação para Partido Republicano Brasileiro (PRB). André Ricardo de Souza (2010) descreve que a nova legenda teria sido criada para atender aos interesses da Igreja Universal, especialmente aos de Marcelo Crivella, sobrinho do Bispo Edir Macedo.

Como observa Burity (2006), o diferencial da IURD é atuar como sujeito político calculador ao analisar, planejar e executar um projeto de transformação de seu crescimento numérico, poderio financeiro e midiático e carisma em representação política, promovendo um credenciamento de interlocução direta com o estado.

Na primeira disputa a um cargo eletivo, Crivella concorreu ao Senado Federal em 2002, pelo Partido Liberal (PL), então com 44 anos e tornando-se senador ao receber 3.243.289 votos, ou seja, 21,6\% dos votos válidos para o senado (MACHADO, 2006). Analisado por Machado (2006) como o resultado do Projeto Nordeste, ${ }^{13}$ uma espécie de "filantropia virtual”, capitalizando as ações sociais no Nordeste e transformando a IURD em uma parceira confiável das agências públicas, somada a propaganda televisiva, jornais e panfletos contendo o seguinte

RJ), na qual ele revelava a existência do pagamento de propina para parlamentares. Mais informações em: <http://www1.folha.uol.com.br/especial/2012/ojulgamentodomensalao/>. Acessado em: 30/11/2017.

13 Projeto Nordeste, conforme aponta Mariano e Schembida (2009), foi propagandeado como "o primeiro kibutz brasileiro implantado com a supervisão de técnicos israelenses" e realizado como um mix de empreendimento social e religioso, constituiu a principal bandeira eleitoral de sua campanha para o Senado Federal em 2002. O projeto compreende a Fazenda Nova Canaã, na cidade de Irecê, Bahia, e de acordo com Crivella, foi possível graças ao repasse integral dos recursos da venda de seus CDs. 
jargão: "Se deu certo no sertão, vai dar certo no Rio". Isso tudo contribuiu para que o candidato ao Senado fosse reconhecido, expressando uma estratégia dos dirigentes da IURD de apostar no engajamento do bispo nas atividades de assistência como as implementadas no sertão, todavia sem ressaltar sua identidade evangélica, tão pouco seu posto hierárquico na igreja, conquistando assim, os votos fluminenses.

Não obstante, o seu vínculo com Igreja Universal como bispo licenciado, seu parentesco com Edir Macedo - fundador e líder da IURD - e o fato de seus dois suplentes serem ambos da Universal, transformaram-se em combustível para que Crivella fosse fortemente atacado por candidatos rivais no horário eleitoral e pela própria imprensa local. Os candidatos oponentes ${ }^{14}$ questionaram a legitimidade de sua candidatura e desqualificaram-no para o posto de senador, acusando-o, dentre outras coisas, de misturar religião com política e de explorar a fé dos pobres (MARIANO; SCHEMBIDA, 2009).

Em 2004, disputou a prefeitura do Rio de Janeiro como um forte candidato atrelado as obras sociais, com uma campanha semelhante à de 2002, mas acabou ficando em segundo lugar com $21.83 \%$ dos votos válidos (753.189 votos). Saindo vencedor em primeiro turno Cesar Maia com 50,1\% dos votos. Novamente assistiu à articulação de seus adversários para inibir sua candidatura, como argumenta Mariano e Schembida (2009, p. 89):

assistiu à estreia do primeiro blog contra sua candidatura, o "crivellanão", cujo mote principal era e é "Ninguém merece o Bispo". Além de colecionar adversários, viu romper-se, a contragosto, sua aliança política com o casal Garotinho. Por conta dos percalços e acusações sofridos, Crivella colocou-se, desde o início da campanha de 2004, na posição de vítima de preconceito e discriminação religiosa, dos quais reclamou

\footnotetext{
${ }^{14}$ Os ataques partiram principalmente dos candidatos Carlos Luppi (PDT), Artur da Távola (PSDB) e Leonel Brizola (PDT), segundo Mariano e Schembida (2009).
} 
insistentemente, especialmente dos ataques desferidos contra ele pelo jornal O Globo. Em resposta, partiu para o ataque contra $\mathrm{O}$ Globo, inclusive em seu programa eleitoral gratuito. O fato é que a campanha de 2004 à prefeitura carioca conteve novos episódios de confronto entre Universal/Rede Record e Organizações Globo, cuja ferrenha rivalidade econômica e política se arrasta desde o finalzinho dos anos 8o. Mas desta vez teve como alvo o candidato Crivella. $\mathrm{O}$ bispo não tinha nem tem como se desvencilhar e nem muito menos deixar de sofrer as consequências dessa disputa, em geral deletérias para suas ambiciosas pretensões políticas. Afinal de contas, não é fácil para um candidato frequente a cargos majoritários de um dos principais municípios e estados do país ter de enfrentar a cada dois anos a pesada artilharia de sua maior empresa de comunicação provavelmente recalibrada com chumbo mais grosso nos períodos eleitorais para provocar maiores estragos nos adversários.

Em 2006, após o escândalo do mensalão atingir seu partido, saiu da legenda e se filiou ao PRB para disputar o governo fluminense contando com apoio do presidente Lula, em detrimento do candidato do próprio Partido dos Trabalhadores (PT), Vladmir Palmeira. Souza (2010) aponta que com apenas 45 segundos de propaganda gratuita na televisão, Crivella conseguiu chegar em terceiro lugar, com 1.531.431 votos. Também é interessante observar que neste mesmo pleito, Crivella em uma entrevista à Folha de São Paulo declarou-se vítima novamente de "preconceito religioso" e de misturar política e religião afirmou ainda que:

\footnotetext{
"Quero o Estado laico, mas quero politizar os evangélicos". Em seguida, condenou as propostas de ampliação do direito do aborto e de união civil de pessoas de mesmo sexo, advogando que "o Estado deve proteger a relação homem e mulher", em consonância com a tradicionalista moralidade sexual pentecostal (MARIANO; SCHEMBIDA, 2009, p. 90).
}

Outro escândalo abalou a candidatura de Crivella, o Escândalo 
das Sanguessugas, ${ }^{15}$ cuja a Comissão Parlamentar Mista de Inquérito (CPMI), no final de agosto de 2006, recomendou a cassação de 72 parlamentares, entre os quais 27 evangélicos, sendo que 14 dos 16 deputados federais da Igreja Universal, por envolvimento no escândalo, responsável por fraudes e superfaturamento na licitação de ambulâncias destinadas a prefeituras. Como frisa Mariano (2009, p. 91): "por sua magnitude e pelo estardalhaço que provocou na mídia e na opinião pública, as denúncias explodiram como uma bomba de fragmentação na campanha eleitoral dos candidatos da Universal ao legislativo, rebentando estilhaços para todos os lados”.

É interessante notar conforme aponta Tadvald (2015) as consequências do escândalo das sanguessugas. Visto que na campanha eleitoral de 2006 (legislatura 2007-2010) certas denominações como a IURD, resolveram preservar alguns campeões de voto envolvidos em escândalos de corrupção não os lançando candidatos, o que acabou diminuindo sensivelmente a Frente Parlamentar Evangélica daquela legislatura, nas demais, o que se tem observado é a manutenção de certo contingente de parlamentares evangélicos.

Depois de perder duas eleições executivas consecutivas e de reconhecer que, nas campanhas anteriores, "era um novato isolado e menos preparado", Crivella começou a corrida eleitoral para a prefeitura carioca, em 2008, em primeiro lugar nas pesquisas eleitorais. Em março, segundo o Datafolha, ocupava a liderança com 20\% das intenções de voto, seguido, por Jandira Feghali (PC do B), Eduardo Paes (PMDB) e Fernando Gabeira (PV). Contudo, tinha o maior índice de rejeição (28\%) de todos os candidatos, rejeição que se ampliaria ao longo da campanha.

${ }^{15}$ Em maio de 2006, a Polícia Federal descobriu o esquema de fraude em licitações para compra de ambulâncias com verba do Ministério da Saúde, por isso, também ficou conhecida como "máfia das ambulâncias". Mais informações em: <http://politica.estadao.com.br/noticias/geral,entenda-o-escandalo-dossanguessugas,20061211p60113>. Acessado: 30/11/2017. 
Contudo, Crivella despertou a militância de grupos homossexuais e feministas contra sua candidatura, ao declarar que Gabeira "defende aborto, homem com homem e maconha" (MARIANO; SHEMBIDA, 2009).

Mesmo assim, ao se lançar mais uma vez como candidato à prefeitura carioca continuou com apoio de Lula e do vice-presidente José Alencar, manteve-se líder nas pesquisas de intenção de voto, todavia, teve seu potencial arrefecido na disputa devido a uma grande controvérsia com o projeto Cimento Social. ${ }^{16}$ Para aumentar sua base eleitoral (seu teto eleitoral ao longo da campanha) e diminuir seus índices de rejeição, Crivella tentou dissociar sua imagem política da Igreja Universal e aplacar os temores sobre eventual concessão de privilégios aos evangélicos e possível discriminação aos católicos e seus opositores. Todavia, a oposição à sua candidatura aumentou. Entre seus adversários constavam seus rivais políticos imediatos: órgãos de imprensa, grupos feministas, homossexuais, religiosos e blogs. A essência das acusações e resistências à sua candidatura repousava sobre a convergência de suas identidades religiosa e política. Crivella, segundo Mariano e Schembida (2009), foi acusado de fazer parte de uma seita intolerante, de ser homofóbico, de instrumentalizar eleitoralmente seu rebanho religioso, de pretender transformar o Estado em veículo de

16 O "cimento social", de acordo com Souza (2010), tratava-se de uma cooperação técnica entre os ministérios da Cidade e da Defesa que liberou 13,9 milhões de reais entre 2007 e 2008 , em que o Exército foi incumbido para atuar como mão-deobra e proteção para as obras. O projeto previa a recuperação de 782 casas em uma área da favela da Providência (centro do Rio de Janeiro), simbolicamente escolhida por ter sido a primeira favela do Brasil. As obras, que começaram em dezembro de 2007, e inicialmente ficariam sob responsabilidade do Exército, foram terceirizadas para a construtora Edil (Souza, 2010, p. 41). Em 14 de junho de 2007 um tenente, um sargento, um soldado e mais 8 soldados cúmplices, entregaram três rapazes - de 17, 19 e 24 anos do morro da Providência a traficantes do vizinho morro da Mineira, dominado por facção criminosa rival, o que lhes causou tortura, seguida de morte. Causando indignação, protestos dos moradores e embrago da justiça carioca. Em síntese, no desenrolar dos acontecimentos Crivella perdeu um trunfo da sua campanha eleitoral, com esse programa de assistência social, embora tenha se mantido um candidato bastante forte. 
pregação religiosa.

É interessante observar que:

Sua propaganda [de Marcelo Crivella] em rádio e tevê, porém, não obteve sucesso, uma vez que despencou para $20 \%$ após o início do horário eleitoral, enquanto Eduardo Paes, concorrendo com o apoio do governador Sérgio Cabral e dispondo do maior tempo na tevê, subiu para $17 \%$, segundo pesquisa do Datafolha. A queda de Crivella decorria da oposição à sua candidatura, mas também do fato de que, dentre os cinco candidatos mais bem colocados nas pesquisas, detinha o menor tempo na tevê, apenas imin55s em cada um dos dois blocos diários. Além de perder quatro pontos percentuais na preferência dos eleitores na referida pesquisa, seu índice de rejeição, em vez de baixar, elevou-se para $35 \%$, colocando em risco suas chances de disputar o segundo turno. Sintomaticamente, sua rejeição era maior entre os mais escolarizados $(58 \%)$, os com maior renda familiar (55\%), os kardecistas (52\%) e os católicos (44\%). Em contraste, seu melhor desempenho ocorria entre os que tinham apenas ensino fundamental e renda familiar até dois salários mínimos, perfil social majoritário nos meios pentecostais (MARIANO; SCHEMBIDA ,2009, p. 97).

Crivella alcançou apenas $625.237 \quad(19 \%)$ votos, sendo ultrapassado pelo candidato Eduardo Paes (PMDB), ficando em terceiro lugar. Tal pleito foi considerado uma grande derrota política para Crivella e para a Igreja Universal (SOUZA, 2010). Portanto, Crivella perdeu a acirrada disputa para Gabeira (25,61\%) pelo segundo lugar, o que se deve segundo Mariano (2009, p. 99), a ascensão meteórica de Gabeira na reta final "impulsionada, em parte, pelo voto útil do eleitorado de maior renda e escolaridade para impedir Crivella de chegar ao governo do Rio de Janeiro. [...], fazendo com que sua performance eleitoral em 2008 fosse inferior à das eleições de 2004 para a prefeitura", quase um mês depois, faltando três dias antes da votação no primeiro turno. Ainda segundo Mariano, estratificada por religião na pesquisa da Folha de São Paulo de 3 de outubro de $2008^{17}$ - ou seja, três dias antes do pleito - havia uma enorme divisão religiosa do eleitorado carioca:

\footnotetext{
${ }^{17}$ Ver em: MARIANO, 2009.
} 
Crivella, tinha $45 \%$ dos votos dos pentecostais e $36 \%$ dos protestantes, mas somente $8 \%$ dos católicos, $6 \%$ dos umbandistas e 3\% dos espíritas.

Em 2010, candidata-se novamente ao Senado e é eleito juntamente com Lindberg Farias (PT). O petista conquistou 4.213.749 votos, o equivalente a $28,65 \%$ dos votos válidos, enquanto Crivella, com 52 anos, recebeu 3.332 .886 votos, o equivalente a $22,66 \%$ dos votos válidos. Disputa novamente o governo fluminense em 2014. No primeiro turno teve como principais oponentes o também evangélico Anthony Garotinho do Partido Republicano (PR) e Luiz Fernando Pezão (PMDB), sendo que Pezão obteve 40,57\% dos votos válidos, Crivella, 20,26\% e Garotinho, 19,73\%. A diferença entre Crivella e Garotinho foi de menos de 50 mil votos.

Já no segundo turno, Pezão obteve a vitória com 4.343.298 votos, o que corresponde a 55,78\% dos votos válidos e Marcelo Crivella (PRB) teve 3.442 .713 dos votos $(44,22 \%)$. Os votos brancos $(3,39 \%)$ e nulos (13,96\%) somaram 1.635.179 votos; houve ainda 2.713.771 abstenções (22,36\%). Somados brancos, nulos e abstenções, chega-se a 4.348 .950 votos, 5.652 a mais que os alcançados por Pezão. Nota-se que esse fato foi decorrente do desgaste político ocasionado desde as jornadas de Junho de 2013, a operação Lava-Jato da Policia Federal e uma campanha recorrente de associação de Crivella com a IURD, a fim de descaracterizar o religioso na política.

A ênfase dada ao cargo de bispo e sua ligação com Edir Macedo demarcaram as estratégias dos candidatos rivais, a fim de ressaltar que os desdobramentos entre laico e religiosos seriam inaceitáveis, uma vez que a penetração nos espaços institucionalizados de representação se dá fora dos canais tradicionais por meio de uma linguagem estranha ao ambiente laicista das instituições, levantando suspeitas sobre as “intenções”, o "grau de compromisso democrático" e a própria natureza do "projeto político" desses novos atores evangélicos (BURITY, 2006, p. 
174). Essa estratégia político-eleitoral torna-se base e principal ponto de oposição aos candidatos evangélicos, notadamente, em pleitos majoritários recorrentemente enaltecido nas últimas eleições executivas no Rio.

De modo breve, ao observarmos a configuração política do pleito de 2016 percebemos algumas peculiaridades em relações as eleições anteriores: com a interrupção de uma série de vitórias do PMDB (em questões eleitorais e de credibilidade partidária); A disputa entre Freixo e Crivella que apresentou - talvez desde o Brizolismo - a presença de uma eleição local que assumiu, evidentemente, contornos nacionais. No qual os embates nacionais voltaram à cena, diluindo os resquícios de uma retórica tecnocrática imune às questões sócio-políticas mais amplas. De fato, os ecos dos discursos antagônicos da conjuntura nacional refletiram com um peso muito maior nas eleições de municipais de 2016, principalmente, nas grandes metrópoles. ${ }^{18}$

\section{Em busca do executivo: performances e estratégias}

Como já demonstrado, o perfil de muitos políticos evangélicos atendendo a lógica das candidaturas proporcionais, acentua posições que os identificam com o segmento religioso, mas isso cria dificuldades quando as eleições são executivas (ALMEIDA, 2017). Nesse sentido, também presenciamos um investimento de importantes lideranças evangélicas em torno de unidade para ocupação de cargos executivos. Sendo que no Legislativo, é mais "fácil”, pois o discurso é proferido para um núcleo - na maioria dos casos na própria igreja. Todavia, para o

${ }^{18}$ No primeiro turno, Crivella obteve $27,78 \%$ enquanto Freixo, $18,26 \%$. No segundo turno ocorrido em 30 de outubro de 2016 , Crivella teve $59,37 \%$ dos votos válidos e Freixo, 40,63\%. Freixo teve 1,2 milhão de votos e seu adversário 1,7 milhão. Pleito em que 150 mil eleitores votaram em branco e outros 570 mil anularam o voto, segundo dados do TSE. Ver em: REZENDE, 2017. 
Executivo tem de conciliar o discurso para a base religiosa com o discurso para a sociedade em geral. Adotando um jogo de visibilidade e ocultação da identidade evangélica dos candidatos. Uma vez que em uma candidatura majoritária não se pode ter referência apenas em uma base, recordando que para vencer uma eleição majoritária são precisos $50 \%$ dos votos mais um, ou seja, a expansão da base eleitoral é fulcral. No caso, Crivella nas eleições de 2016 objetivou essa expansão da base ao ativar elementos que não são - ao olhar mais descuidado - religiosos, como enaltecendo a fala sobre o cuidado com as pessoas, da atenção, e motivação da individualidade (REZENDE, 2017).

Crivella tenta na maior parte da sua campanha afastar-se da imagem da IURD na tentativa de abranger sua base eleitoral, conforme afirma Mariano e Schembida (2009, p. 101): “torna-se perfeitamente compreensível a disposição de Crivella, [...], para tentar desvencilhar-se dela [IURD], relegá-la a um plano secundário, ou tratá-la simplesmente como uma opção pessoal restrita à intimidade ou à vida privada". Empenhando-se durante as sucessivas campanhas ao executivo - carioca e fluminense - se mostrar como um agente público, um gestor, na tentativa de isolar a Universal inteiramente de sua denominação religiosa e de sua função de liderança eclesiástica.

Contudo, tal estratégia não surte o efeito esperado devido ao seu insucesso em demonstrar sua autonomia política da Universal, uma vez que a IURD apresenta sua própria atuação política por meio de seu vínculo partidário com o $\mathrm{PRB}$, partido criado por membros $\mathrm{e}$ representantes da Igreja. Em outras palavras, a forte e ativa presença da Universal no campo político acaba impossibilitando a total desvinculação de Crivella com a instituição religiosa.

De outro modo, a IURD apresenta uma forte presença no cenário político nacional, portanto, a tentativa de dissociação tornar-se muito pouca efetiva, além do fato de que a Universal realiza campanhas 
de modo a incentivar o voto colocando sua mídia (Televisão e Folha Universal) para favorecê-lo. Bem como os ataques desferidos por seus dirigentes eclesiásticos contra os adversários políticos e midiáticos de Crivella. Como enaltece Mariano e Schembida (2009), decorre do embaralhamento de seus papéis político e religioso nas campanhas eleitorais e no desempenho da atividade parlamentar.

Percebemos assim, que Marcelo Crivella não consegue dissociar o senador e político do bispo neopentecostal. Mas, ao mesmo tempo, temos a ciência de que suas ações constituem uma íntima relação com sua base eleitoral, ou a enaltece de modo a demarcar sua filiação religiosa perante a mesma, por outro lado, também devemos estar cientes que tais ações decorrem de seu mandato de eleição proporcional (senador), o que em processos para o executivo, sua estratégia de campanha é outra, baseada em discursos mais amenos e de certa forma, tentando ser mais abrangentes e inclusivos - sem perder ao mesmo tempo o apoio de sua base eleitoral -, ao investir na opção de explorar temas de preocupações sociais da IURD como no início de suas campanhas, ao priorizar os pobres nordestinos no Projeto Canaã e mais recentemente no slogan, “cuidar das pessoas”. Ou seja, evidenciando o capital social.

O envolvimento desses religiosos com a política partidária, o ativismo político dos pentecostais e, a própria, articulação dos poderes públicos e os governantes tendem a reforçar a presença e a influência do religioso na esfera pública. Desse modo, a própria democracia brasileira não pode ser pensada sem a análise desses processos e suas implicações para as instituições democráticas e o espaço público. De qualquer modo é importante ressaltar, como argumenta Machado (2006), que o corporativismo e mesmo as práticas clientelísticas - como visto até agora - extensivamente denunciadas pela imprensa não são características exclusivas/específicas dos atores evangélicos, muito menos são 
expressões inéditas da articulação política brasileira. Desse jeito, os pentecostais e neopentecostais estariam reproduzindo um comportamento político já identificados em outros grupos e sujeitos sociais. Ou seja, a cultura política transforma-se numa diretriz capaz de orientar e mimetizar tais ações em outros coletivos sociais.

E de modo a evidenciar o deslocamento do político para outras áreas do social diante da crise de esgotamento institucional da política, notamos a religião como um norte fundamental para o ordenamento político nas eleições. Pois, de fato, a cada nova eleição no Brasil a maioria dos candidatos a cargos legislativos e executivos, até mesmo os que disputam à presidência da República, pedem, barganham, disputam e reclamam o apoio eleitoral das lideranças pentecostais (MARIANO; SCHEMBIDA, 2009, p. 104). Ao passo que muitos governantes, por sua vez, cobram dos parlamentares evangélicos, sobretudo os pentecostais, apoio político a seus mandatos. Apoio que procuram angariar em troca da oferta de concessões a eles e a suas denominações. Tais práticas, como revela Mariano e Schembida (2009), têm por efeito incrementar e naturalizar a participação, a influência e o poder desses religiosos no plano político-partidário. Como aponta os autores (2009, p. 105):

por isso, a desprivatização política desse movimento religioso, ocorrida a partir dos anos 8o, não decorre somente do vigoroso empenho de muitos líderes pentecostais para transformar seu rebanho religioso num rebanho eleitoral e ampliar sua representação política, visando dilatar sua influência na esfera pública e defender seus interesses institucionais, suas crenças, suas práticas e seus valores morais. Decorre também da incansável disposição de candidatos, partidos e governantes não-evangélicos, movidos por interesses políticos os mais diversos, de enredá-los nos pleitos eleitorais e no jogo político-partidário. Resulta disso que soa à pura hipocrisia, ou a oportunismo político, a defesa discursiva da laicidade estatal por muitos desses políticos.

Por consequência, relacionar a atuação dos evangélicos com a cultura política brasileira é fundamental, a fim de desvelar que os 
comportamentos políticos aludidos se decorrem de práticas corriqueiras da própria cultura política nacional. Bem como percebemos por meio da literatura aqui apresentada, a capacidade de proselitismo e do alinhamento do comportamento político com os interesses corporativista das Igrejas, almejando como destaca Freston (1993): fortalecer lideranças internas; proteger a socialização sectária; acessar recursos para a expansão religiosa e disputar espaço na religião civil.

Não obstante, devemos considerar a baixa credibilidade nos políticos tradicionais e nas instituições políticas ao tomarmos como base a pesquisa realizada ICJ Brasil (Índice de Confiança na Justiça) produzido pela Escola de Direito de São Paulo da Fundação Getúlio Vargas - que revela a queda na confiança da população em praticamente todas as instituições analisadas; na qual apenas $7 \%$ dos entrevistados confiam no Congresso Nacional, 7\% nos Partidos Políticos e 6\% no Governo Federal $^{19}$. O que tende a favorecer e corroborar a escolha do eleitor por candidatos sem experiência em cargos políticos (outsiders), “gestores", ou que se apresentam como salvacionistas da moralidade pública. Visualiza-se assim, o deslocamento do político e a capilaridade da religião e do moralismo como forças política e social na atual conjuntura conturbada brasileira. ${ }^{20}$

\section{Considerações finais}

Sob o cenário apresentado no presente artigo, Burity (2015, p. 94) argumenta que: "estamos às voltas com performances e retórica, mas também com uma demanda por reconhecer a objetividade do que se

19 Pesquisa disponível na íntegra em:
<http://direitosp.fgv.br/sites/direitosp.fgv.br/files/arquivos/relatorio_icj_1sem2o17.pdf> . Acessado em: 07/12/2017.

${ }^{20}$ Sobre confiança institucional e instituições religiosas ver: GRACINO JÚNIOR, TARGINO e REZENDE, 2018. 
passa nela ou nela se expressa, sua 'visibilidade', seu 'desenrolar no tempo', sua vinculação com outros processos”. Em que a religião pública da forma que é vista e avaliada por quem está "fora" dela (como críticos, como simpatizantes, como guardiães da legalidade etc.), instaura um problema de hospitalidade, de modo que: como permitir a "entrada" desses atores religiosos na circunscrição da vida pública - especialmente quando saem da vida pública cultural e cotidiana e incursa na vida pública da política - nesse sentido como os repertórios discursivos dos espaços sociais reconhecem a legitimidade de suas "credenciais" ou as repudiam? O cenário sociopolítico é, assim, um lugar de ansiedade, contestação e tentativas de controle.

Dois elementos tornam-se fulcrais para análise apresentada: “o reconhecimento da contingência radical das relações sociais e da pluralidade irredutível de formas, identidades e práticas que demarcam a compreensão do mundo que muitos contemporâneos assumem ou contra a qual se batem outros tantos" (BURITY, 2015, p. 95). Ou seja, por meios desses processos a "emergência” evangélica pode parecer surpreendente, perturbador ou inaceitável a muitos, principalmente a alguns intelectuais ou políticos que se dispuseram a praticar e defender uma clara delimitação de fronteiras - entre o religioso e o político -, sobre os papéis e o impacto social da religião na esfera pública contemporânea.

Cientes dessas reverberações no espaço público moderno e, notadamente, na conjuntura brasileira atual, a situação política é de persistente e reificada polarização. O conservadorismo tornou-se ponto de discurso central para qualquer ação deliberada de um segmento religioso. Todavia, temos que tomar cuidado com tais preciosismos, mesmo se todos os grupos religiosos - dentro das miríades de denominações evangélicas - fossem, de fato, conservadoras, não é algo contrário às normas democráticas, entretanto, no enquadramento do 
debate público há uma sobreposição na identificação de conservadores, fascistas e fundamentalistas. Tais arquétipos vêm das amplificações dos atores religiosos evangélicos na arena política democrática, principalmente por meio da imprensa, acerca das ações da FPE nos últimos anos.

Com a força política e econômica as pautas de ordem moral têm sido canalizadas de forma mais contundente no Poder Legislativo. É importante frisar que não podemos relativizar as posições dos evangélicos pentecostais a partir dessas posições. Pois, quando se intensificou no país o debate público em torno das pesquisas com células-tronco embrionárias, bem como o da legalização do aborto, a Igreja Universal declarou-se a favor das pesquisas e admitiu o aborto nos casos já definidos pela legislação brasileira (feto com anencefalia, estupro e perigo de vida para a mãe). ${ }^{21}$ Para alguns autores, tais posições foram uma forma da Igreja Universal se colocar na discussão em contraposição à Igreja Católica.

O importante destacar é que, em nosso cenário contemporâneo, há uma presença/circulação indiscutível do religioso em busca de eficácia política, que gera um adensamento em discursos políticoreligiosos como fonte de capital social. Muito se decorre ao tripé, assistencialismo, política e mídia das instituições religiosas que auferem maior aderência e coerência normativa aos seus fiéis e demais segmentos sociais que acabam sendo receptores dessas ações. Bem como esvaziada de credibilidade e de eficácia a política estaria "preenchida" por "novos" atores sociais, como os evangélicos. Derivado de um processo de esgotamento do político, que se expressa no reconhecimento da perda de interesse pela política decorrente de uma avaliação negativas sobre suas prática, instituições e políticos tradicionais; apatia participativa no

${ }^{21}$ Além de se posicionarem nessa relação os setores mais liberais do protestantismo histórico como a Igreja Metodista e a Igreja Presbiteriana. 
espaço público; erupção de escândalos de corrupção nos altos escalões do poder; e principalmente no caso carioca, a incapacidade do poder público de dar soluções paras os graves problemas de desigualdade social, violência e insegurança.

\section{REFERÊNCIAS}

ALMEIDA, Ronaldo de. 2017. A onda quebrada - evangélicos e conservadorismo, Cadernos Pagu, São Paulo, n. 50, 2017.

BURITY, Joanildo A. Políticas de minoritização religiosa e glocalização: notas para um estudo de redes religiosas de ativismo sócio-político transnacional. Revista Latinoamericana de Estudios sobre Cuerpos, Emociones y Sociedad, Buenos Aires, $N^{\circ}$ 18, Año 7, 2015, p. 19-30.

- Religião e Política na Fronteira: desinstitucionalização e deslocamento numa relação historicamente polêmica. Revista de Estudos da Religião, São Paulo, n. 4, 2001, p. 27-45.

Religião, voto e instituições políticas: notas sobre os evangélicos nas eleições de 2002. In: BURITY, J. A; MACHADO, M. D. C. Os Votos de Deus: evangélicos, política e eleições no Brasil. Recife: Fundação Joaquim Nabuco; Massangana, 2006.

FRESTON, P. Protestantes e política no Brasil: da Constituinte ao impeachment. 1993. Tese de Doutorado em sociologia, Campinas: IFCH-Unicamp, São Paulo, Brasil.

MACHADO, Maria das Dores Campos. Política e Religião: a participação dos evangélicos nas eleições. Rio de Janeiro: Fundação Getúlio Vargas, 2006.

Evangelicals and Politics in Brazil: the case of Rio de Janeiro.

Religion, State \& Society, v. 40, n. 1, $2012 a$.

. Religião, Cultura e Política. Religião e Sociedade, Rio de Janeiro, v.2, 2012b, p. 29-56.

MARIANO, Ricardo. Neopentecostais: sociologia do novo pentecostalismo no Brasil. São Paulo: Loyola, 1999. 
Efeitos da Secularização do Estado, do pluralismo e do mercado religiosos sobre as igrejas pentecostais. Civitas, Porto Alegre, v. 3, n. 1, junho, 2003.

- Expansão e ativismo político de grupos evangélicos conservadores: secularização e pluralismo em debate. Civitas, Porto Alegre, v. 16, n. 4, 2016, p. 710-728.

; SCHEMBIDA, Rômulo Estevan de Oliveira. O Senador e o Bispo: Marcelo Crivella e seu Dilema Shakespeariano. Interações: Cultura e Comunidade, v. 4, 2009, p. 85-111.

ORO, Ari Pedro. A política da Igreja Universal e seus reflexos nos campos religioso e político brasileiros. Revista Brasileira de Ciências Sociais, São Paulo, v. 18, n. 53, 2003.

A Igreja Universal e a política. In: BURITY, Joanildo; MACHADO, Maria das Dores Campos (orgs.). Os votos de Deus: evangélicos, política e eleições no Brasil. Recife: Massangana, 2006.

REZENDE, Gabriel S. A ordem dos fatores altera o produto? A vitória de Crivella nas eleições para o executivo Carioca de 2016. Agenda Política, São Carlos, v. 5, 2017, p. 87-113.

SMIRDELE, Carlos Gustavo Sarmet Moreira. Modernização à brasileira: o tempero pentecostal da política nacional. Rio de Janeiro: Outras Letras, 2013.

SOUZA, André Ricardo. Os evangélicos nas eleições municipais. Revista Correlatio, n. 17, jun, 2015.

TREVISAN, Janine. A Frente Parlamentar Evangélica: Força política no estado laico brasileiro. Numen: revista de estudos e pesquisa da religião, Juiz de Fora, v. 16, n. 1, 2013, p. 29-57.

TADVALD, Marcelo. A reinvenção do conservadorismo: os evangélicos e as eleições federais de 2014. Debates do NER, Porto Alegre, ano 16, n. 27, p. 259-288, jan./jun., 2015.

VITAL DA CUNHA, Christina; LOPES, Paulo Victor Leite; LUI, Janayna. Religião e Política: medos sociais, extremismo religioso e as eleições 2014. Rio de Janeiro: Fundação Heinrich Böll; Instituto de Estudos da Religião, 2017. 